\title{
Designing Application of M-Learning based on Content Management System
}

\author{
Arief Hidayat \\ Department of Information \\ System \\ STIMIK Pro Visi \\ Semarang, Indonesia
}

\author{
Hendro Purwanto \\ Department of Informatic \\ Technology \\ STIMIK Pro Visi \\ Semarang, Indonesia
}

\begin{abstract}
Innovation in the telecommunications technology develops fast and aligned with the development of modern society characteristic that have high mobility, flexible, easy and satisfying search service, and the pursuit of efficiency in all aspects. Currently, the use of mobile device like mobile phone, pocket PC and PDA (Personal Digital Assistant) has become a common sight in everyday life. Commonly used mobile devices, most are able to perform data communication via the Internet. This development makes people able to develop a method of learning that is based on wireless and mobile technology, called mobile learning (m-learning). Mlearning has its own characteristic because of the limitations of mobile device. Merging mobile web technology with Content Management System can become alternatives in developing m-learning applications. Designing m-learning based on content management system aims to simplify the management of content. M-learning generated in the form of mobile web that accessed by users through mobile phone. The m-learning is expected to be one of the alternatives in the delivery of study materials to students.
\end{abstract}

\section{Keywords}

m-learning, web mobile, content management system

\section{INTRODUCTION}

Conventional learning activities (learning system) still plays an important role in the learning process, especially when viewed from the effectiveness of knowledge transmission process and the process of communication and interaction of individuals. Such learning activities allow direct communication and interaction between students and lecturer and among the students themselves so that the delivery of content, feedback and questions answering and dialogue can occur directly. Visualization clearly defined learning process through a variety of media. Visual, verbal, gesture, and expression interfaces contribute to determine the understanding of the processes learning activities that take place.

The main drawback of the conventional learning is the limited time utilization. This is associated with the distribution and provision of space and scheduling of learning activities for teachers. These activities involve various stakeholders, especially teachers and students. Learning activities need a shared commitment on time and place. The condition is certainly not flexible so that time utilization for learning activities is very limited.

The development of information technology puts information technology as a data communication technology and the delivery of information technology quickly and effectively.
Educational challenges ahead will be determined by the information network that enables to interact and collaborate.

Nowadays, there are a lot of developing e-learning systems in education, an effective learning process created by combining digital technology to deliver supporting material and learning services [1]. Several years ago, teachers and students have been getting a lot of benefits with the cable technology to access the internet. However, the cable technology offers limited access, especially regarding mobility. E-learning by using cable technology can't provide services anywhere and at any time, to offer mobile and wireless technologies [2]. Rapid advance in mobile and wireless technology creates an opportunity for new research sector, which is referred to as 'mobile learning' (m-learning). [3].

Mobile learning can be defined as a facility or service that provides general information electronically to the learner and the educational content which helps the achievement of knowledge without questioned the location and time. [4]. Mobile learning system takes advantage of the nature of the mobility of handheld device / mobile, such as mobile phones and PDAs, to provide learning functionality at any place at any given time.

Previously made mobile learning applications has disadvantage on the lack of material management thus the discussion is limited to only one kind of material. M-learning applications are often unable to run on multiple types of mobile phones. Users are required to have a mobile phone with specific mobile phone technology such as Java 2 Micro Edition (J2ME), Binary Runtime Environment for Wireless (BREW), Symbian or Flash Lite, in order to consume the mlearning services.

Mobile web is a technology to develop mobile learning applications. Mobile web become the minimum standard of mobile phones in the current market. Merging mobile web technology with Content Management System (CMS) may be an alternative to build m-learning application. In this research, mobile device refers to cell phone, PDA and smart phone.

\section{MOBILE LEARNING}

\subsection{Definition of Mobile Learning}

Along with the increase of mobile technology in business and society, many individuals and organizations seriously consider using mobile devices for learning and training. Mobile learning or m-learning is often defined as e-learning through mobile computing devices. Ally et al [5] defines mlearning as the delivery of electronic learning materials on mobile computing devices to be accessed from any place and at any given time. 
In general, the mobile device is referred to PDAs and digital cell phone, but in general, we can consider it as any device that is small enough, it can work itself, which can accompany us in every moment of our daily lives, and which can be used for some forms of learning. This small device can be seen as a tool for accessing content, either stored locally on the device or reached via the interconnect. The device can also be a tool for interacting with other people, through voice and through the exchange of written messages, still images and moving images.

\subsection{Differences m-learning with e-learning}

There are several different things that are found when compared to the mobile device with a desktop PC (the media used to deliver e-learning) and such differences include the features, functionality, and comfort even on any device. Some of the differences include the output (i.e. screen size and resolution capabilities, etc.), input (i.e. keypad, touch-screen, voice input); processing power and memory; supported applications and media types. In order to port e-learning service onto m-learning service, some things must be changed to meet the limitations of a small device, and some may not be delivered within the constraints of a specific context, but on the other hand, new service may also be raised, triggered by the mobility of mobile devices [6].

According to Andi [6], m-learning limitation as drawback is one-side of the service. At the other side of the m-learning weakness, the system also has several advantages compared to the e-learning system, namely:

1. Portability: mobile devices more portable and easier to make records or enter data anywhere.

2. Learner support: the current generation prefers mobile devices such as PDAs, cell phones, and handheld gaming device.

3. Increase motivation: ownership of mobile devices tends to increase the commitment to use and learn.

4. Wider range: mobile devices tend to be cheaper which lead to wider public affordability.

5. Learning time: improving work or learning performance learning according to learners' needs.

\subsection{Content Management System}

Content Management System (CMS) is software that provides tools / devices for manufacturing, publishing and managing [7] a website, which presenting information or knowledge to the user.

Content is a unit of digital information that is used to fill a webpage [8]. Such content include electronic files, images, audio files, video or documents electronically.

CMS is widely used on the internet, for both private and public websites. Some examples of CMS as personal usage are in personal websites and blogs. While example of CMS usage as public websites can be seen on website for company, organization, educational institution or a particular community, portal, photo gallery, and e-commerce applications and e-learning applications.

Some of benefits derived from including the following CMS system [9]:

1. Data management supports multiple formats such as HTML, XML, PDF, etc. since all processes run automatically.
2. Web templates that provide reference to the entire contents of the established site in such way that it may not be changed arbitrarily.

3. Split between design and content that can be displayed in accordance with the wishes and needs of its users.

4. Supported data formats are varied from the RSS, RDF, XML to back-end scripting.

5. Create portals (community sites), forums, photo galleries, e-commerce, e-learning, and others.

CMS (Content Management System) consists of two elements [9], i.e.:

1. The content management application (Content Management Application, [CMA]), where the CMA element allows someone who may not have knowledge of HTML, to regulate the manufacture, modification, and removal of content from a Web site with no need of expertise of a Webmaster.

2. The content delivery application (Content Delivery Application [CDA]), where CDA element uses and collects information that previously had been added, subtracted or altered by the website owner to update or renew such web sites. Capabilities or features of a CMS system may vary, even so, most of the software features a Web-based publishing, format management, revision control, manufacturing index, search, and archiving.

\section{SYSTEM DEVELOPMENT METHOD}

Systems development method used in this research adopting the System Development Life Cycle (SDLC) using waterfall approach which consists of system planning, system analysis, system design, system implementation, and system maintenance, for the last stage is not done, because it takes quite a long time.

\subsection{Process Modeling}

Related parties in a system within an organization as whole entity are called a use-case business. All parties related to the organization are the users of the system, so the grouping of parties is called the membership. In the m-learning system the related parties are administrators, teachers, and students. Business use case for m-learning is shown in Figure 1.

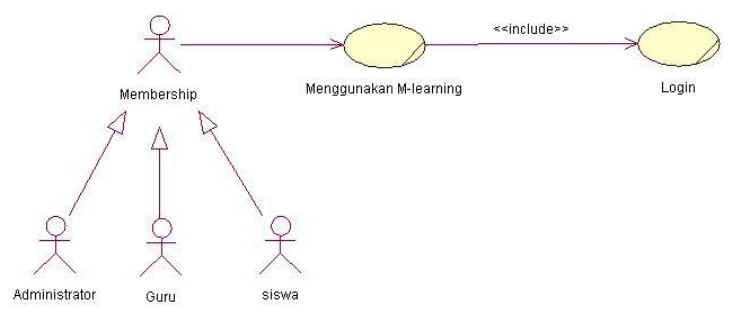

Fig 1: Business Use Case of the Related Parties

Administrators, teachers, and students are users of m-learning, so that generalization between the parties concerned with the so-called membership. Users are required to login first in order to access the m-learning system.

Teachers in the m-learning system can view, add, edit, and delete classes, view, add, edit, and delete subjects, see, add, edit, and delete the material, as well as create, edit, and delete quizzes according to the material that has been made. 
Teachers can also see the results of the test, see, add, edit, and delete announcements.

Students are users who visit m-learning services. Students are also required to login to be able to access the m-learning material as well as administrators and teachers. Students can see the materials according to the subject selected and levels. Students can also take the test contained in each material to determine students' understanding of the material being taught. Students can also access the announcements displayed in the m-learning system.

\subsection{Data Modeling}

M-learning applications use database as storage that consists of 8 tables, while the relationships between the tables shown in Figure 2.

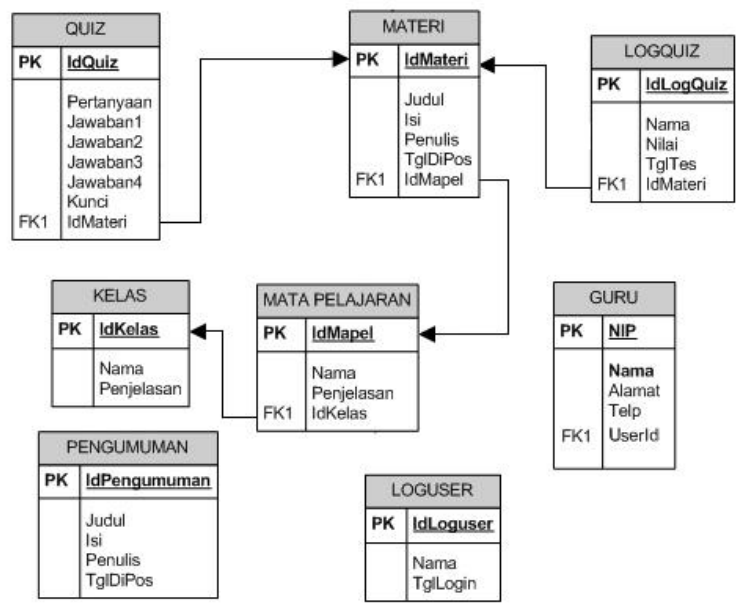

Fig 2: Table Relationship in m-learning Application

M-learning system is composed of interrelated tables which is bound and connected each other, where each tables associated by its primary key (PK). Kelas table has a primary key, IdKelas, which relates to MataPelajaran table. MataPelajaran table's primary key, IdMapel, makes relation with Materi table and Guru table. Materi table's primary key relates to Quiz table and LogQuiz table, which has foreign key to IdMateri. Pengumuman table and LogUser table are standalone tables and unrelated to the other tables.

\section{RESULT AND DISCUSSION}

\subsection{User Page Views}

User page views a display that will be seen by users of mlearning system using mobile phone. Users can access the mlearning by choosing the menu at the top. For example, the materials used to access the page on the m-learning material. Users will be able to choose the level of access to the material (class), subjects, and selecting materials. Page views users are shown in Figure 3

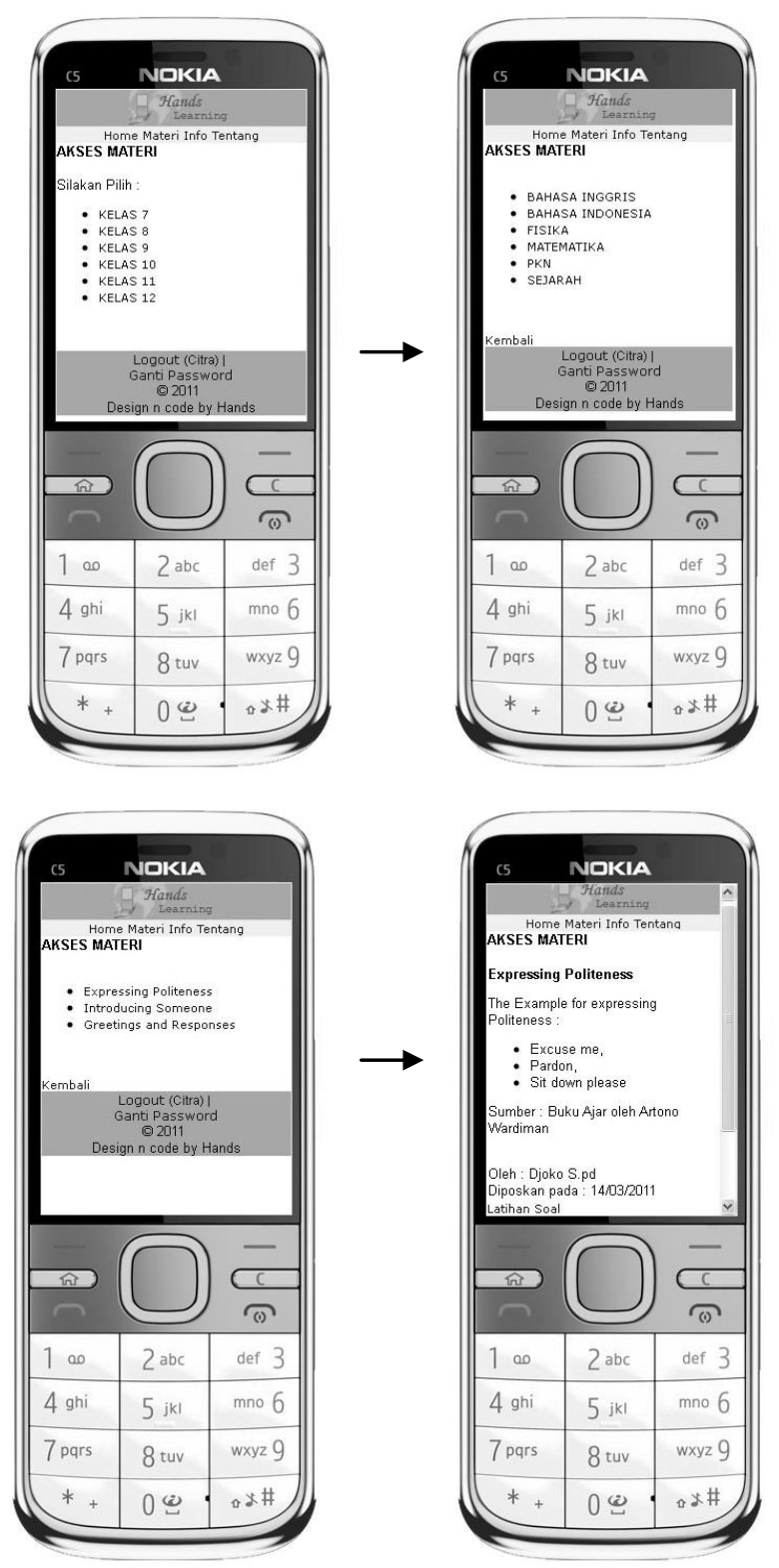

Fig 3: M-learning Access to Select Classes, Subjects, and Materials

\subsection{Administration Page Views}

The administration page consists of three main menu namely content, logs, and accounts. Menu content performs administrative functions on the content, such as classes, subjects, materials, quizzes, and announcements. Material menu is served to manage course material. On this page, the displayed data show subjects that have been made.

The addition of the material can be easily as shown in Figure 4. Log menu functioned to view information access on users that have accessed the m-learning system. 


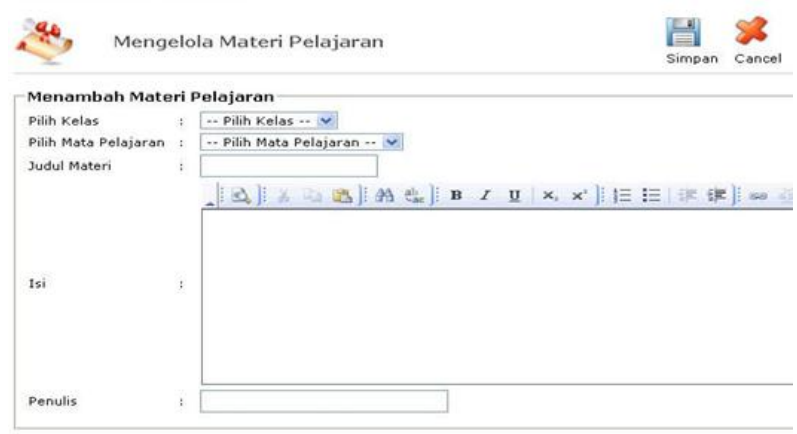

Fig 4: Add page subject material

User log menu functioned to view information access on users that have accessed the m-learning system as shown in picture 5. Quiz log menu displays data of user that has been following exercises. The information displayed are the user name, date of test is taken, the title of the material, and mark.

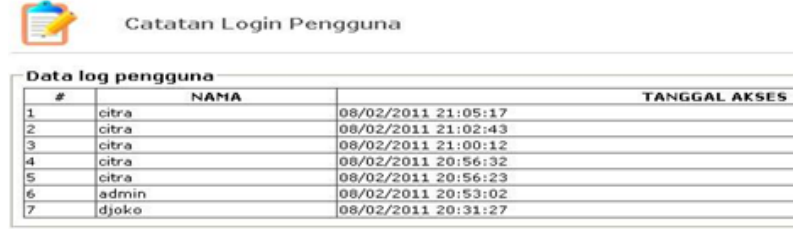

Fig 5: User log management page

User management page performs user account management, as shown in Figure 6. Account menu consists of 2 main menus, i.e. the user and the user's role. User page holds ability to add users, change user data, and provide user access rights to users. User page displays information about user.

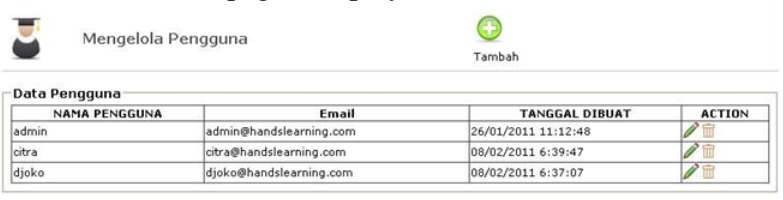

Fig 6: User management page

\subsection{Application Testing}

M-learning tested using black box method. Black-box testing is a testing program based on the function of the program. The purpose of this black box method is to find errors in the program functionalities based on the results of the test execution. The outputs of the designated m-learning applications have met the expected result so it can be concluded that the m-learning content management system based design is successful.

M-learning application is generated based on content management system (CMS), which has the advantage, among others;

1. Divide the display into two parts for the front end user and the back end administrator or teacher, who manages the content of the m-learning.

2. Content management can be done via computer desktop, mobile device usage is not mandatory.
3. Management of CMS-based m-learning requires no technical knowledge.

\section{CONCLUSIONS}

Based on the results and discussion of the design of $\mathrm{m}$ learning applications based on content management system (CMS), it can be concluded that the application of m-learning can be applied at various levels of education as a media for distance learning. Content material can be tailored to the needs, considering the application is based on CMS. The contents of m-learning can be managed without the need to have knowledge about technical matters, because it is already back end management already provided.

M-learning applications still needed development, according to user requirements, such as the addition of features download the material, the addition of audio and video contents (content) of the material, the type of questions that varied in a quiz, and a video conferencing for interaction between students and teachers.

\section{REFERENCES}

[1] Waller, V. And Wilson, J. 2005. Open Learning Today. Open and Distance Learning Quality Council.[online] http://www.odlqc.org.uk/odlqc /n19-e.htm.

[2] Landers, P. 2002. From e-learning to m-learning [online].

http://learning.ericsson.net/mlearning2/project_one/thebo ok/chapter1.html\#stats

[3] Trifonova, A. and Ronchetti, M., 2003. A General Architecture for M- Learning.[online] http://eprints.biblio.unitn.itq/archive/00000493/01/A General Architecture for M-Learning mICTE2003.pdf.

[4] Lehner, F., Nösekabel, H. and Lehmann, H.. 2001. Wireless E-Learning and Communication Environment: WELCOME at the University of Regensburg. [online] http://SunSITE.Informatik.RWTH-

Aachen.de/Publications/CEUR-WS//Vol-61/paper2.pdf.

[5] Ally, M., Lin, F., McGreal, R. and Woo, B. 2005. An Intelligent Agent for Adapting and Delivering Course Materials to Mobile Learners. [online] www.mlearn.org.za/CD/papers/Ally-an-intelligent.pdf.

[6] Andi, Yonatan. 2007. Perancangan dan Implementasi Mobile Learning untuk Pembelajaran Bahasa Jepang berbasis BREW. Sekolah Teknik Elektro dan Informatika Institut Teknologi Bandung.

[7] Robertson J. 2003. So What is Content Management System?, KM Coloumn.[online] http://www.steptwo.com.au/papers/kmc_what/

[8] TreeWorks. 2005. Content Management System, Bucuresti, Romania.[online] http://www.scribd.com/doc/17748/ContentManagementSystems-TreeWorks-White-Paper.

[9] Sadat. 2008. Content Management System. [online]. http://akhsa.wordpress.com/2008/02/14/contentmanagement-system-cms 